\title{
Neither Poor Nor Rich But "Malcontent": An Anotomy of Contemporary Environmentalisms
}

\author{
Bengi AKBULUT ${ }^{\star}$
}

\begin{abstract}
Proliferation of environmental movements, both in number and in geographical-spatial scope, has certainly been one of the markers of contemporary times. The analytical frameworks within which the wealth of issues posed by contemporary environmental movements are to be addressed, however, have largely lagged behind. This paper problematizes, in particular, the ability of the existing literature to accurately capture the underlying motivations of environmental movements. It illustrates, by utilizing a case study of a resistance against a coal plant in Gerze, Turkey, that a type of environmental activism that cannot be explained by livelihood concerns or post-materialist values is emerging and becoming increasingly common.
\end{abstract}

Keywords: Environmental movements, environmentalism of the poor, environmentalism of the rich, Gerze, environmentalism of the malcontent.

\section{Fakirler, Zenginler, Hoşnutsuzlar: Güncel Çevre Hareketlerinin Bir Anatomisi}

\section{Özet}

Çevre hareketlerinin hem niceliksel hem de coğrafi kapsam açısından hızla yükselişi kuşkusuz günümüzün siyasi-toplumsal manzarasını şekillendiren en önemli gelişmelerden birisidir. Ancak, bu hareketlerin tartışılabileceği analitik yaklaşımların bu yükselişe ayak uydurabildiği söylenemez. Bu makale, mevcut yazının çevre hareketlerini motive eden saikleri açımlama konusunda sınırlı kaldığı noktalara değinmektedir. Bu çerçevede Gerze'de yapılması planlanan termik santrale karşı gelişen direnişi tartışarak, geçim kaynaklarını koruma amacı

* Dr., Araştırmacı. E-mail: fungarella@gmail.com 
veya post-materyalist çevre değerleriyle tam olarak açıklanamayan bir tür çevreciliğin varlığını ve yaygınlı̆̆ını ortaya koymaktadır.

Anahtar Kelimeler: Çevre hareketleri, yoksulların çevreciliği, zenginlerin çevreciliği, Gerze, hoşnutsuzların çevreciliği

\section{Introduction ${ }^{1}$}

Proliferation of environmental movements, both in number and in geographical-spatial scope, has certainly been one of the markers of contemporary times. This should not come as an entire surprise: as forms and strategies of capital accumulation are reiterated and expanded within the neoliberal era, existing constellations of society-environment-economy relationships at multiple (local, regional, national and transnational) levels are also being dislocated and reconfigured. Leaving aside, for the moment, the problématique of how to define the (contested) term "environment" (e.g. Cronon, 1995; Smith, 1984), such movements span a range of issues including enclosures and dispossession, access to resources, the quality of the atmosphere and water, loss of soil productivity, loss of genetic biodiversity, deforestation, and toxic contamination. From the anti-dam movement in Narmada Valley, India, to the "Water Wars" spurred by the attempted privatization of water in Cochabamba, Bolivia; from the Ogoni movement against pollution and contamination by oil production in Nigeria to the Bergama resistance against gold mining in Turkey, an array of voices and forces mobilized around environmental issues have acquired increased visibility and stimulated public debate.

Partly as a result of the conjecture they arise out of, and are shaped by, the issues, demands and challenges surfaced by contemporary environmental movements are arguably more complex than ever. On the one hand, the grievances and discourses mobilized by them are increasingly staging a type of politics not only as pertaining to their specific local contexts but also as challenges to state power, processes of capital accumulation, and neoliberal re-structuring of political, economic, social settings. On the other hand, they evoke variegated languages, actors, motivations, trajectories and engagements with the broader constellation of economy-societyenvironment relationships (Adaman, Akbulut \& Avc1; 2012; Dwivedi, 2001).

Not least due to the specificity of this day and age, the contemporary era of environmentalism(s) thrusts obvious challenges together with the novel and intricate food for thought they provide. One such challenge lies in the inadequacy of our concepts and frameworks to capture and explicate the wealth of issues set forth by the existing as well as emerging forms of environmental mobilizations.

1 This paper builds substantially on various lines of collaborative research done over the years. The author would like to thank Fikret Adaman, Murat Arsel and Duygu Avc1 for the thought-provoking conversations and collaborations, out of which many of the ideas that found its way to this paper were developed. They are, in effect, co-authors of this paper. 
This is not only an analytical shortcoming but also -and perhaps more importantly- one of critical political implications, as we lack an understanding of the transformatory potentials of environmental mobilizations as counter-movements.

This paper aims to unpack this inadequacy and to offer a conceptual intervention as a step towards producing a more nuanced grasp of environmental movements. To this end, it first presents a brief review of the environmental movements literature, highlighting the juxtaposition of livelihoods-based vs. post-materialist motivations that largely marks this literature. After pointing out the drawbacks of such a dichotomous understanding, it introduces a case study of an environmental resistance in a coastal town in northern Turkey, Gerze, to demonstrate how a type of environmentalism that transcends the existing categorizations of environmentalism was animated. The paper concludes by drawing attention to the growing capacity of local environmental mobilizations to reveal and politicize the larger political-economic dynamics that spur environmental conflicts and the role of a nuanced understanding of environmental movements would not only illuminate but also contribute to this potential.

\section{Environmental Movements: A Quick Tour d'Horizon}

The academic literature as well as the social imaginary on social mobilizations around environmental issues has been dominated by a focus on the environmental movements in the global North for a long time (Dwivedi, 2001). With the massive transformations that societies and environments (predominantly of the global North) were undergoing during the post-war era, such as the rise of mass production and the corresponding patterns of consumption, extension of vast transportation and communication networks, and unprecedented patterns of urbanization and suburbanization, societal concerns over air and water pollution, toxic waste, urban decay, wildlife conservation, etc. arose as markers of environmental movements in the North. Thus we have witnessed, for instance, the establishment of organizations such as the World Conservation Union (later to become International Union for Conservation of Nature and Natural ResourcesIUCN), the World Wildlife Fund (WWF) and the Greenpeace.

The often-accepted argument is that the economic boom of the post-war era and the broader sharing of its fruits by the society have shifted the focus of politics from quantitative aspects of distribution to qualitative aspects, such as environmental quality. Environmental politics and movements have come to be seen (and to some extent, they have indeed been) largely divorced from politics articulated around socio-economic justice and redistribution. Dubbed as an exemplar of post-materialist values, environmental movements were implied to be a "luxury" of the middle- and upper-income classes (Dwivedi, 2001; Inglehart, 1981; Guha \& Martinez-Alier, 1997; Offe, 1985). Whether or not this was an accurate description of the underlying mechanisms of how environmental movements in the North developed aside, the implication was that a political consciousness around environmental issues could only come about after a certain level of material welfare is fulfilled, and -perhaps more importantly - that environmental politics were largely independent of class-based politics of (economic) justice. 
The corresponding analytics within which environmental movements have been gauged moved along two broad trajectories. On the one hand, the New Social Movements (NSM) literature highlighted not only the chronological antecedence of environmental movements to class-based politics, but also the new subjectivities, agencies, values, conflicts and inequalities they have animated (Melucci, 1989; Offe, 1985; Touraine, 1985). In that sense, the NSM literature illuminated the forms and dynamics of injustices and struggles that cannot be reduced to economic interests and conflicts. The resource mobilization theory, on the other hand, has taken a different analytical path and focused on issues related to the organizational dimension of environmental movements. It has, accordingly, attended to the mobilization of different resources, organizational processes and strategic decision-making in the course of a movement's emergence, its premise being that the mere presence of social grievances does not necessarily lead to the existence of collective action around them.

Notwithstanding the illuminating bodies of work that have been produced within them, important shortcomings had been pointed out with both the new social movements and the resource mobilization approaches. While NSM was criticized mainly for its implicit assumption that action (in the form of movement) naturally follows from discontent -however "new" a form that discontent takes-, the resource mobilization framework came under attack for its portrayal of movements as simply a series of rational-strategic decisions of collective action. Both lines of thinking, however, shared a preoccupancy with environmentalism in the North and a corresponding blindness of fundamentally different motivations and actors involved in environmental struggles. This vision was challenged, more visibly in early 1990s, by a number of scholars drawing attention to the distinct character of environmental concerns and demands voiced by environmental movements in the global South (Bryant, 1992; Gadgil and Guha, 1995; Guha and Martinez-Alier, 1997; Peet \& Watts, 1996; Redclift, 1987; Shiva, 1991). Far from being rooted in post-materialist motivations, such mobilizations were intimately tied to the protection and viability of livelihoods, sustenance and modes of living primarily of the marginalized and the poor. More often than not, it was argued, that struggles giving impetus to environmentalism in the South were around expropriation of resources and degradation precipitated by practices of the powerful and advantaged sections of the society. These processes, on the other hand, inflicted loss of access to resources, deteriorating livelihoods, and harmful health impacts on the disadvantaged. This much-welcome intervention highlighted the political-economic character of environmental struggles in the south by revealing how the processes of environmental change are both precipitated by uneven power-laden relationships and have uneven implications for different groups in the society, i.e. that worsening environmental quality has "winners" and "losers".

Within this context, the term "environmentalism of the poor" has been coined by MartinezAlier $(2002,2013)$ to distinguish an increasingly significant genre of environmental movements from "environmentalism of the rich". Accordingly, Martinez-Alier identifies two dominant currents within environmental movements of the north: While the conservationist drives praise the notion of a pristine "Nature" best preserved when untouched by humans and thus locate the roots of environmental destruction in human involvement with nature, eco-efficiency arguments 
understand the environmental problem not in human-environment interactions per se, but rather in the irrational and unplanned use of resources. Thus while the former lends itself to enclosures of space and nature in the name of restoring environmental quality (often with exclusionary and marginalizing effects on certain social groups) in terms of policy-making, the latter delegates the solution to efficient use and emphasizes the role of rational planning and technological progress to release the pressure of human activity on the environment.

Environmentalism of the poor, by contrast, emphasizes the large populations around the world depend on the environment in fundamental ways to reproduce their sustenance, and mobilize in defense of the environment as the source and requirement for livelihoods in the face of environmental change. In this sense, it reveals the existence of a motivation (i.e. protection and reclamation of livelihoods) and the mobilization of a social group (the poor) that are fundamentally different than environmentalism of the rich. It does so by positing an inherent stake of the (rural) poor in protecting the environment as they have a direct livelihood link with natural resources. With a geographical scope that extends beyond the third world, environmentalism of the poor thus illuminates the constitution of a different valuation language over the environment, held by those who depend on it for their very existence, and often bear the disproportionate effects of environmental change. The term has since been a strong analytical tool to investigate the different languages of valuation that are at play in environmental conflicts (e.g. protection of livelihoods, monetary valuation, values of sacredness, etc.) the power relations underlying the imposition of a certain language, and the types of resistances and struggles that have erupted in response.

Notwithstanding the value of the environmentalism of the poor vs. of the rich framework, as well as that of the substantial body of work it has inspired, it is nevertheless marked with similar limit that haunt much of the existing literature on environmental movements; namely the dichotomous understanding of environmental movements through the juxtaposition of livelihoods-based vs. post-materialist motivations. The shortcomings of such a perspective and its ultimate tendency to oversimplify the wealth of complexities found within environmental movements are especially visible in this day and age of burgeoning environmental mobilizations around the world, and have been discussed at length by several scholars. Dwivedi (2001), for instance, delineates the problematic tendencies in the portrayal of livelihoods-based environmental mobilizations, including the positing of local communities as the prime actors of movements and the envisioning of them as containing seeds of "new visions of development" (Dwivedi, 2001).

More generally, it has been repeatedly pointed out that the motivations, actors, actions, strategies, and ethico-politics animated within contemporary environmental mobilizations cannot adequately be captured within the existing analytics of binaries (Dwivedi, 2001; Adaman, Akbulut, Avc1, 2012; Akbulut, Adaman, Arsel, 2013). Within this context, attempts have been made both to develop more nuanced and multi-dimensional categorizations to frame environmental mobilizations (Adaman Avc1, Akbulut, 2013; Dwivedi, 2001; Castells, 1997) and to delineate the dynamics within the different trajectories they take (Adaman, Akbulut \& Avc1, 
2012; Dwivedi, 2001). While the former highlights that the motivating demands and interests of an environmental mobilization is merely one, and not necessarily the most contextually-relevant, distinguishing factor and that there is no one-to-one mapping between underlying motivations and a well-defined group of actors and scales, e.g. those who articulate livelihood demands are not only the poor, and vice versa, the latter conceptualizes environmental mobilizations as a process and emphasizes the dynamic interplay of the motivations, actors, alliances, and transformatory potentials they animate through this lens. Within this context, for instance, Adaman et al. (2012) proposes a theoretical toolbox drawing upon the works of Karl Polanyi and Antonio Gramsci, to investigate the dynamics of environmental movements, focusing on the contextual conditions of their emergence, the reactions and responses they trigger, the alliances and key actors they mobilize and the underlying understanding of society-economy-environment relationship they embrace.

In a related manner, it is often the case that neither the class boundaries of the actors involved in environmental movements nor the motivations and demands voiced by them can be neatly delineated. The contemporary era of environmentalism, in particular, bears witness to the engagement of groups whose motivations and demands vis-à-vis the environment do not comfortably fit within the categories of post-materialist values of the rich and the livelihoodbased interests of the poor: while their motivations cannot be easily be ascribed to an attempt to defend their livelihoods, they realize a far more direct engagement with the resources and movements they support than environmentalism of the rich would allow (Akbulut, Adaman \& Arsel, 2013; Adaman, Akbulut \& Arsel, 2013). Although they can fulfill crucial roles in raising awareness, agenda setting, and translating and transmitting widely shared political, economic and environmental concerns to broader audiences (Akbulut, Adaman \& Arsel, 2013; Mawdsley, 2004), scholarly work on environmental movements have been curiously silent on their motivations and mobilizations. The growing mobilization of such groups and of motivations begs to be elaborated on in order to grasp not only the novel and distinct features it displays, but also the potentials for progressive social change they carry.

The following section utilizes the case of a resistance against a coal plant near Gerze, in the northern coast of Turkey, to illustrate the role played by one such group of actors in Yeşil Gerze Platformu (Green Gerze Platform; YEGEP), the mobilization's locomotive organization. Livelihood and health concerns, or place-based feelings of attachment and belonging, although important, cannot adequately describe the motivations of this group in resisting the coal plant. Sharing a history of engagement in organized radical left in late 1970s, the languages and positions they portray often reflect fundamental challenges to the Turkish state, not only (or predominantly) for its performance on environmental issues, but more importantly for its support for (global) capital, neglect of rural well-being, and disregard of democratic policymaking. The term "environmentalism of the malcontent" is coined to describe the environmental politics animated by this group: what mobilized them to resist the particular development project envisioned for the area is long-lasting dissatisfaction with the broader processes marking the development trajectory of the country and resentment brought by their exclusion from shaping these processes. 


\section{Environmentalism of the Malcontent: The Anatomy of an Anti-Coal Resistance ${ }^{2,3}$}

On September 5th, 2011, the news of the Black Sea town Gerze hit national news, where locals blocked and forced out drilling machines that showed up at $4 \mathrm{am}$. Accompanied by the police and the gendarmerie, the aim was soil exploration and sample acquisition for the coal plant to be built in Yaykil, one of the villages within Gerze township's jurisdiction. ${ }^{4}$ When hundreds poured into the village gate to block the drilling attempts, alerted and directed by the impeccable communication network of YEGEP, the police resorted to using teargas to pave the way-a strategy that proved unsuccessful as over 1000 people confronted the police and prevented the vehicles from entering the village. Although this was the main incident that provided broad-based recognition of the conflict in Gerze, the locals by then had been fighting against Anadolu Group for nearly three years in multiple fronts, from legal struggle to guard watching over the territory, raising public support at the national and local levels, and to organizing demonstrations.

The conflict in Gerze sparked by the proposed construction of a thermal power plant, which built up to a local resistance movement that was named among the 10 victory cases by the Sierra Club, dates back to late 2008 (Sierra Club, 2012) when the Anadolu Group, a large conglomerate mostly known for its popular beer brand Efes, obtained the official permit from the Energy Market Regulatory Board (EPDK). If constructed, extending over an area of 80 ha of arable land, forests and existing settlements in Yaykil and operating with a capacity of $1200 \mathrm{~mW}$, GES was to be the second largest thermal power plant to be operated by a private company in Turkey. When functional, the plant would burn 11,500 tons of coal per day (to be imported from Russia) and could emit not only toxic gases that can affect an area of up to $200 \mathrm{~km}$ of diameter with the prevailing winds, but also "dead water" as it will dump the warmed-up seawater vacuumed in for cooling the system and damage the sea eco-system, let alone the high probability that it will kill masses of fish during water intake.

Local organization against the power plant gained momentum with the few prominent locals, most importantly the Mayor, ringing of the alarm bell and the subsequent founding of YEGEP

2 This section builds heavily on the collaborative work carried out in Akbulut, Adaman \& Arsel (2013). It is based on fieldwork conducted as a part of this collaborative work between July-September 2012. Over 40 interviews, most of them semi-structured, were conducted in Gerze and Yaykil in addition to participation observation, which included two meetings of YEGEP. All names of activists from Yaykll and Gerze have been replaced with pseudonyms in the interest of their privacy and security.

3 The term "anti-coal" is used throughout to refer to the fact that the proposed project was to make use of coal for energy production.

${ }^{4}$ Yaykll is a village of 180 households located on the coastline, $7 \mathrm{~km}$ north of the town centre of Gerze, where agriculture is the main source of livelihood albeit often supported with other economic activities. It is known to be one of the well-to-do villages in Gerze, as it holds most of the arable land in the area, and the villagers have direct access to the market in the town centre. All households own some land, and the average size of landholdings is 2-to-3 ha. It is often told that the affluent families of the area are those rooted in Yaykul, who have accumulated agricultural wealth and expanded into trade and small business in the town centre. It is, therefore, hardly surprising that the coal plant's potential impact on agricultural production has proven to be the main mobilizer of the villagers. 
by the residents of the town center in 2009. ${ }^{5}$ Organizing for the following two years consisted of local demonstrations such as protest picnics, rallies, meetings, and sporadic confrontations with company employees who showed up for soil explorations, as well as a significant legal battle initiated by the locals. The resistance started to acquire a more heated face after mid-2010. Most notably, the informatory meeting held by the Anadolu Group was flooded by some three thousand protesters and subsequently cancelled after intervened by the police use of batons and teargas. It was, however, the unfolding of events in 2011 that put the Gerze resistance on the spot in national as well international attention. In early August, after being tipped that the company had applied to run exploratory drills, Yaykıl Villagers and YEGEP put up a guard-watching tent and ensured, via collaborative labor, that it stayed populated and active, night and day. Anadolu Group made two attempts to enter the village not long after, both accompanied by police and gendarmerie forces, only to be blocked and repelled by a sizable crowd of locals from the village as well as Gerze after long scuffles.

These two incidents, as signifiers of Anadolu Group's insistence on building the plant despite substantial local resistance and the police's use of physical force, conjured large public outcry. They have also intensified mobilization efforts on the side of YEGEP, as several rallies were organized and gave new impetus to the legal struggle as the cause then acquired broader public legitimacy. The legal venues of the struggle indeed took an optimistic turn in 2012 for the mobilization, with the Directorate of Forestry disapproval of the project and demand for revision and resubmission. After the rejection of the revised project plan as well in early 2013, the final decision on the coal plant proposal was made in late August, rejecting it on grounds that there was no exigency of constructing such a plant in a forest area.

As the above discussion suggests, the resistance movement in Gerze stands on two more or less distinct groups, YEGEP and the villagers in Yaykıl. YEGEP itself, on the other hand, is a broad front, a coalition built between actors who differ widely in many other respects-mostly in terms of political stances and socio-economic backgrounds. Its membership has purposefully tried to keep the organization as broad a front as possible by preventing it from being identified with any specific political movement or major political party, which has been one of the most notable factors contributing to its success. ${ }^{6}$ Founded in 2009 , the organization gave the resistance a public face and an international fame; the visibility that the resistance achieved within these three years owes much to the meetings, rallies, solidarity picnics, and petitions organized by YEGEP. Since the news of the proposed thermal plant was first heard, the organization was pivotal in collecting and

5 Villagers started campaigning against the plant already in early 2009, before YEGEP was formally established. In February 2009, a meeting was held in Yaykll by the villagers, with the participation of around 40 people from Gerze, and a public statement was read by the village head against the thermal plant.

6 YEGEP's caution on this issue has at times been costly: after being criticized - and reprimanded - for their explicitly political slogans about the Kurdish issue in Turkey during a march, most of the extreme nationalists within YEGEP have withdrawn their active engagement despite remaining as members. Similarly, the local branch of Halk Evleri (People's Houses), representing the orthodox organized left, has officially pulled out of YEGEP while continuing to support the anti-thermal cause after pronounced discontent due to what has been widely perceived as attempts to dominate the movement and make it a venue for their own political agenda. 
disseminating knowledge about it. It has successfully mobilized the resources and networks of its members to access technical and legal information related to both thermal power production and potential strategies of resistance, and disseminated the collected information effectively by holding meetings and distributing leaflets in Gerze as well as surrounding towns and villages. ${ }^{7}$ The organization has also been instrumental in building alliances with different environmental NGO's, such as Greenpeace, and environmental movements that emerged contemporaneously, such as the Platform for the Sisterhood of Streams and the Black Sea in Revolt. It established links with academia (mostly forestry and environmental sciences departments of nearby universities), and initiated communication with other anti-thermal resistances in Turkey. ${ }^{8}$

The diversity among the constituents of the resistance reflects on the variety of (valuation) languages employed within the movement. Yaykıl villagers are articulating their opposition mostly in health and livelihood terms. Languages related to health concerns are commonly framed in terms of breathing/breath: as put by one Yaykll woman "if there is no breath, there is nothing". When voicing their concerns about air pollution, the villagers describe vivid pictures of a grey-black landscape (most probably informed by thermal plant experiences in other parts of the country) and effectively mobilize a right-to-live rhetoric since breathing is the start of all life. In terms of livelihood, it is emphasized that agriculture, the main source of livelihood in the village, would be irreparably damaged if the thermal plant were constructed. A claim they often make is that with the air pollution caused by the plant nothing will grow in Yaykıl. That the arable land in Yaykll is of the highest quality is often brought up to support their position. One villager states "the land [in Yaykil] is sacred. Whatever you cultivate ripens. The land gives its best to anything you put in it".

This livelihood-based language of opposition often goes hand-in-hand with feelings of belonging and values attached to land-as a family holding, as an asset that generations of labor and care have been invested in. In the words of one village woman (among those who laid in front of the army vehicle) "[t]his is my land, my home. I do not know how to live somewhere else. They say they are going to move us to a village in Elmadağ [a village near Ankara in central Anatolia]. Why would we leave our house, our land and go there? Everything we have is here, we won't leave". Similar positions and feelings were expressed by almost all villagers. There is also a sense

\footnotetext{
7 The most decisive of these activities has been the arrangement of trips to two towns with operating thermal plants, during which they interviewed the locals on the impacts of the plants and made video recordings. Recordings and interviews were then shared in a meeting attended by almost 1500 people in Gerze-a turning point in the mobilization according to many-as well as in smaller meetings in the surrounding villages.

8 Another factor underlying YEGEP's achievements is the past experience of its core membership in political organizing. As will be discussed, a significant number among YEGEP members has taken part in left organizations before the military take over in 1980's. This experience was productively carried into the movement in Gerze in terms of devising organization strategies, networking, accessing information and achieving public visibility. Past (and current) political connections of the core membership proved highly valuable as well. Alliances with other local environmental resistances and information sharing often operated through these connections: for example, the trips to two towns with operating plants, which gave decisive impetus to the resistance, were arranged by using such networks.
} 
of gratitude towards the land, due to its fertility that has supported the villagers for so long, which is transformed into a feeling of responsibility to defend the land itself in addition to the human livelihood on it. "If you are not resisting the thermal plant, then you are giving the land, of which you have been eating the fruits, to the thermal company", says one village woman.

Compared with what can be called the environmentalism of the poor articulated by Yaykil villagers, the posture of YEGEP sits less comfortably within existing classifications of environmentalism. The leadership and overall vision of YEGEP is indisputably dominated by a group of "ex"-radicals who share a history of anti-state, anti-capitalist action. Nevertheless, they have purposefully tried to keep the organization as broad a front as possible by preventing it from being identified with any specific political movement or major political party, effectively building a coalition and navigating the momentum thus emerged. Along general lines, this group is between the ages of 50-60, educated, retired professionals/public servants who have acquired some-but by no means much-economic security; they have experienced rising living standards, but they remain financially fragile, most of them subsisting on retirement income with little accumulated wealth. Furthermore, the group has long-established bonds among itself dating back at least 30 years ago and feels a sense of belonging, not only to the town itself, but to each other.

As stated above, what is remarkable about this "core" group is the fact that almost all of them had been engaged with organized radical left prior to the 1980's coup détat, albeit typically in clashing factions. With the coming of the military rule, a few had been arrested and tortured, but all had been traumatized, repressed and ripped from their prior political engagements. Like many of their counterparts in the country, post-1980 implied a detachment from active politics for this group, partly due to military oppression and the crushing of the left, and partly due to the feelings of resentment and cynicism towards politics in general. Even when the political climate became friendlier for the left, they have chosen to stay out of active engagements, with a few exceptions. It seems that-mostly personal-confrontations with the shortcomings of the pre-1980 left politics and a critical stance against the existing left organizations have added to this de-activization process. Political organizing seems to have been substituted with commitment to local cultural activities and taking part in NGO's with no explicit political agenda. Albeit a few are now engaged with political parties of the left and center-left, none have cultivated nor became engaged with a mobilization of comparable size and commitment, even on issues of direct local relevance, such as the waves of privatization that resulted in the shutting down of the two big state-owned enterprises in Sinop-a strong blow to the local economy.

When elaborating on the reasons for which they oppose the coal plant, the languages used by this group are in line, to a certain extent, with those voiced by the villagers. Concerns about the health impacts of the plant are reiterated by many, often with reference to past thermal plant experiences in Turkey, and with some emphasis on their unpredictability. The narratives around the motivation to retain a healthy environment go parallel with feelings of belonging and values attached to Gerze's spatiality, which incorporates the uniqueness and beauty of the environment and the landscape; its historical reputation as a social democrat/leftist town; the prevalence 
of small town/neighborhood dynamics where "everyone knows each other and each other's family. We all know what we are made of. You cannot have this in a big city". Although highly romanticized at times, this attachment to the spatiality of the town has not only cemented the core group of YEGEP organizers closely to each other, but also helped them effectively mobilize different groups in the area with diverse motivations to resist the plant.

What stimulates the core group in YEGEP, however, goes beyond narrowly-defined concerns about health and feelings of belonging: they do not, for instance, slip into a NIMBY-type rhetoric. In fact, they have explicitly challenged and tried to change positions drawing upon a narrow focus on Gerze alone as a part of their organizing practices: "Sometimes we heard people say that [Anadolu Group] should go and build the thermal plant elsewhere. We say 'No' to that, too. We explained to everyone who is with us that a project that threatens human life and the environment should not be allowed anywhere". They frame their resistance most emphatically as a struggle in broad progressive terms that coalesce around progressive notions of a dignified life, "the most basic right one should be entitled to". Cevat, for instance, states that "the struggle for the right to live is the most basic of all. It forms the foundation of all other struggles, all the struggles that the left takes on, that is why we are here". Zühre draws an even more explicit parallel between left politics and environmental resistance: "We are opposing [the coal plant] with socialist ethics and ideas, in order to defend the right to a dignified life no matter where. It is the same motivation both in socialist struggle and the anti-coal resistance. This is what underlies our dedication and our effort". A similar position is articulated by Nurgül: "Our responsibility is towards [Gerze] but also towards all the people. Why would anyone be able to make profits by exploiting our living spaces and us? This is why I am opposed to the plant". It is also worth noting that this line of opposition is often coupled with broader democratic demands, that "nothing that the local people oppose should be built here", as repeated by many.

There are important aspects in which the environmentalism of YEGEP's core organizers is distinct. Although they sympathize and voice solidarity with the villagers, it is clear that the motivations of this group for opposing the coal plant do not rest on livelihood-based concerns, as none of them draws sustenance from the economic activities in the village. In fact, a somewhat critical evaluation of the motives on which Yaykll villagers' build their opposition is invoked as well: "Sometimes it seems as if [the villagers] would cave in if they did not lose their land and have to move elsewhere. This is a serious weakness in the resistance and we should watch out for it. If the only issue is not to lose land, then there is no real resistance spirit and the state can buy [the villagers] out or coerce them into accepting the project", says Zühre.

It is clear that a motivation to protect the environment in order to maintain personal affluence or the existence of post-materialist values do not explain what drives this group, either. Similarly, the mobilization of this group is not based on preservationist, romanticized notions of environmental protection. Indeed, it seems that environmental issues were not so much on their agenda prior to the thermal plant proposal: "Of course we were (...) hearing of environmental issues on the news but we were not really paying attention to them [before the coal plant project]. Come to think of it, we did not care all that much", states Ömer. The fact that most of them would 
not be opposing a proposal to open a factory, even though it would also have negative impacts on the environment, also attests to that.

The environmental politics animated by YEGEP's core group can be denoted as "the environmentalism of the malcontent" (Akbulut, Adaman \& Arsel, 2013): What has mobilized them around the anti-coal cause goes beyond livelihood, health or place-specific motivations, but rather a dissidence with the state rooted in their political history. The particular local environmental issue has served as a common ground through which this long-lasting dissidence has found a voice. As described above, this group shares not only a history of significant political engagement with the left, but also the trauma of experiencing a brutal coup d'état and political repression. Normalized mechanisms of voicing and articulating grievances were cut off abruptly with the military regime. Such forced silencing of societal demands, coupled with the resentment induced by having experienced the military takeover, made the anti-thermal resistance an instrument of "getting even" with the state-as well as of demonstrating that they have not been defeated and they will not succumb. ${ }^{9}$ The quote below demonstrates this point concisely:

"What is happening here is called an environmental struggle, but it is not in fact an environmental struggle. It is a revolt. The name of the enemy here is the Anadolu Group, but we are fighting against the gendarmerie, the police. We are fighting against the state. Our struggle lasted for 12 hours on the night of September $5^{\text {th }}$. Such a long struggle never happened anywhere, not even during [the coup d'état]. It was not a struggle for land, it was a one-to-one fight with the security forces of the state. (...) What emerged was a stance against the state. Resistance against the plant is now a secondary issue, at least for us. I am fighting the state. The villagers should also know what the state is like."

Obviously, particular, and largely context-specific, factors enabled the malcontent of this core group to be mobilized into an effective environmental mobilization. First of all, the anti-coal cause is a strongly unifying one, rather than a particular issue that concerns some but not all. It (literally) hits close to home for all of them since the imagery attached to Gerze is highly valuedwhich includes not only personal histories, social relations and the physicality of the area, but also the town's leftist tradition and rebellious reputation. Secondly, particular characteristics of YEGEP's core group, as well as the specific milieu in which they operate, seem to have acted as a facilitator. Compared to the pre-1980 era, this group holds more social, political and financial resources at their disposal as they are much better connected and economically securer. Several of them are members of CHP (Republican People's Party, the major oppositional party), through which they could access crucial political networks and legal/technical knowledge. The familiarity of this group with each other has been a major factor in establishing the much-needed trust and solidarity bonds in initiating and maintaining the collective labor for local organizing. In fact, the shared malcontent as a mobilizer itself implies a comraderie and solidarity against the state. That is to say, malcontent is rather different than what can be called particularistic motivations, such

9 This account also explains, to some extent, the relative absence of the town's youth in the resistance. 
as narrower individualist concerns with health or livelihood, in that it is somewhat spontaneously embedded in solidarity and mutual care.

Finally, the fact that the malcontent of the group was not -and to some extent, could not have been- expressed via alternative venues has contributed for this particular type of environmentalism to emerge. The bluntness of the coup and the absence of a process of confrontation afterwards seem to have perpetuated and accumulated their dissent. Added to this is their disillusionment with the left in general and the fact that they have not been satisfied with any organized political movement enough to become engaged with. They criticize the existing left organizations for their persistent problems of dogmatism and internal divisions. In that sense, it seems that the environmental cause in Gerze has not only substituted left politics, but made up for what it lacked with regards to human emancipation. For instance, Cevat states that environmental resistances will breathe new life into the left all around the world, since "[p]eople always mobilize when it comes to their local environments. Not only in Gerze, this is the case everywhere. Here the environmental struggle has united all these people's energies, which the left could not for years. It's because the fight for life is a unifying one. After all, the fight for a dignified life is the underlying logic of left politics".

\section{Conclusion}

This paper has made the case that existing frameworks of varieties of environmentalism that rely on a juxtaposition of livelihood-based concerns of the poor and post-materialist and/ or conservationist attitudes of the rich, although holding significant analytical import, remain increasingly inadequate to understand contemporary environmental movements. In doing so, it has utilized a case of an anti-coal mobilization in the northern coast of Turkey, where a broader political project endorsed by a core team of organizers was the engine driving the resistance. Building on the observation that this group's motivations and discourses transcend the existing frameworks of varieties of environmentalism, the term "environmentalism of the malcontent" is coined to illustrate that what was mobilized through their resistance went beyond livelihood or health concerns or feelings of belonging. Sharing a history of engagement with the radical left in the late 1970s, the trauma of the coup d'état in 1980 as well as the period of de-politization and rapid neo-liberalization in its aftermath, this group's dissent towards the state found voice via this environmental issue.

Movements such as the one taking place in Gerze reveal that environmental concern can glue together actors from across the political spectrum, forging a broad coalition that not only seeks to prevent massive environmental degradation but also transform the state and its relationship with society. Although this paper has focused on a particular context, where the dynamics underlying malcontent are rooted in the configuration of state-society relationships, the link between grievances about the broader political-economic setting and environmental mobilizations are 
by no means specific to Gerze. ${ }^{10}$ The intense struggles around small-scale hydropower plants in Turkey, for instance, can be seen as depicting similar dynamics in terms of the alliances struck and the discourses utilized (Adaman, Akbulut \& Arsel, 2013). In that sense these mobilizations begin to provide counter-points to what has been widely observed about environmental resistances: their general tendency to remain confined to the localities they are embedded in, failure to reveal and intervene in the broader, more structural processes whose materializations spur the environmental conflicts in their specific contexts, and their rare translation into a demand for transformation and for producing equitable socio-ecological conditions for all (Kaika and Seyngedouw, 2011).

The conceptualization introduced here explicates the birth of such new environmental struggles — not only in Turkey but across the developing world - that build upon cross-class alliances to resist development projects that simultaneously threaten peasant livelihoods and overall ecosystem health, on the one hand, and encapsulates larger processes of (state-led) neoliberal capital accumulation. It highlights the potential of such alliances to challenge the broader political-economic setting in which they are embedded. In that sense, it helps illuminate new forms, languages, actors and motivations whose constellation provide a fertile breeding ground for the emergence of a politics that not only reveal the link that connects localized environmental struggles, but also transform it.

${ }^{10}$ Following Gramscian theorizations of the state, the prevention of certain groups' articulation and voicing of demands can be seen as an inherent component of state rule. More specifically, states incorporate and further certain interests while excluding others in establishing and legitimizing their existence. One the one hand, hegemonic projects depend on the construction of a collective outlook in order surpass multiple interests in the fragmented domain of the society and the production of the image of the state as representing the "universal interest". On the other hand, states are selective in allowing the formulation, representation, and articulation of social demands, as those demands that are fundamental threats to the hegemonic project and the collective outlook are denied validity and access to the state (Gramsci, 1971; Poulantzas, 1978; Jessop, 1982). 


\section{References}

Adaman, F., B. Akbulut and M. Arsel (2013) “Türkiye'de Kalkınmacılığı Yeniden Okumak: HES’ler ve Dönüşen Devlet- Toplum- Doğa İlişkileri [Re-reading Developmentalism in Turkey: SmallScale Hydropower Plants and the Transformation of State-Society-Environment Relationships]", unpublished manuscript.

Adaman, F., B. Akbulut and D. Avc1 (2012) "Polanyi Meets Gramsci: Explaining Local Environmental Conflicts", presented at the 12. International Karl Polanyi Conference, Buenos Aires, November 2012.

Adaman, F., B. Akbulut and D. Avc1 (2013) “Ekolojik Paylasima Dayali Ihtilaflarin Kategorilendirilmesine Yonelik Bir Taslak Calismasi” [“Categorization of Conflicts over Ecological Distribution: A Working Proposal"], Üç Ekoloji, 10.

Akbulut, B., F. Adaman and M. Arsel (2013) "Environmentalism of the Malcontent: Anatomy of an Anticoal Power Plant Struggle in Turkey", unpublished manuscript.

Baviskar, A. (2003) "Between Violence and Desire: Space, Power, and Identity in the Making of Metropolitan Delhi”, International Social Science Journal, 55(175): 89-98

Bryant, R. (1992) "Political Ecology: An Emerging Research Agenda in Third-World Studies", Political Geography, 11(1): 12-36.

Catells, M. (1997) “The Power of Identity” in The Information Age: Economy, Society and Culture, Vol. II, Oxford: Blackwell.

Cronon, W. (1995) The Trouble with Wilderness, or, Getting Back to the Wrong Nature, in W. Cronon (ed.) Uncommon Ground: Rethinking the Human Place in Nature, New York: W. W. Norton \& Co., 69-90.

Dwivedi, R. (2001) "Environmental Movements in the Global South: Issues of Livelihood and Beyond", International Sociology, 16(1): 11-31.

Gadgil, M. and R. Guha (1995) Ecology and Equity: The Use and Abuse of Nature in Contemporary India, London and New York: Routledge.

Gramsci, A. (1971) Selections from the Prison Notebooks, New York: International Publishers.

Guha, R. ve J. Martinez-Alier (1997) Varieties of Environmentalism: Essays North and South. London: Earthscan.

Inglehart, R. (1981) "Post-materialism in an Environment of Insecurity", The American Political Science Review, 75: 880-900.

Jessop, B. (1982) The Capitalist State: Marxist Theories and Methods. New York and London: New York University Press.

Kaika, M. ve E. Swyngedouw (2011) “The Urbanization of Nature: Great Promises, Impasse, and New Beginnings", in G. Bridge and S. Watson (eds.) The New Blackwell Companion to the City, Oxford: Blackwell, 567-580.

Martinez-Alier, J. (2002) The Environmentalism of the Poor: A Study of Ecological Conflicts and Valuation, Cheltenham: Edward Elgar.

Martinez-Alier, J. (2013) “The Environmentalism of the Poor”, Geoforum [online], http://dx.doi.org/10.1016/ j.geoforum.2013.04.019

Mawdsley, E. (2004) "India's Middle Classes and the Environment", Development and Change, 35(1): 79-103.

Melucci, A. (1989) Nomads of the Present: Social Movements and Individual Needs in Contemporary Society, ed. J. Keane and P. Mier, London: Radius.

Offe, C. (1985) "New Social Movements: Challenging the Boundaries of Institutional Politics", Social Research, 52(4): 817-868. 
Peet R. ve M. Watts (eds.) (1996) Liberation Ecologies: Environment, Development, Social Movements, 2. Edition, London: Routledge.

Peluso, N. L. and M. Watts (2001) Violent Environments, Ithaca: Cornell University Press.

Poulantzas, N. (1978) State, Power, Socialism, London: New Left Books.

Redclift, M. (1987) Sustainable Development: Exploring the Contradictions, London: Methuen. Shiva, V. (1991) Ecology and the Politics of Survival, New Delhi: United Nations University/Sage.

Smith, N. (1984) Uneven Development: Nature, Capital and the Production of Space, Oxford: Blackwell.

Touraine, A. (1985) "An Introduction to the Study of Social Movements", Social Research, 52(4): 749-788. 